\title{
PATRIMONIO FAMILIAR E INFORTUNIOS FINANCIEROS DEL LINAJE DE LOS CASTELLVÍ DURANTE EL SIGLO XVII
}

\author{
Family Assets and Financial Misfortunes of the Castellvi \\ Family during the 17th Century
}

Amparo FELIPO ORTS

Universidad de Valencia

Correo-e: amparo.felipo@uv.es

RESUMEN: La rama del linaje valenciano de los Castellví iniciada a principios del quinientos por el señor de Puchol protagonizó durante el siglo XVII un significativo proceso de acumulación patrimonial. En el origen del mismo se sitúan las adquisiciones realizadas por los sucesivos miembros que lo encabezaron, pero tan importante como ello resultó la estrategia matrimonial de los titulares del linaje, el reducido número de hijos y la reversión a la línea principal de legados de los miembros de la familia que no contrajeron matrimonio o fallecieron sin descendencia. En contrapartida, diversos factores se conjugaron para provocar un endeudamiento progresivo, especialmente acusado desde la década de 1670 en que herencia y deudas se anudaron en permanente complicidad. Analizar los pormenores de este doble proceso y su repercusión para la Casa constituye el objetivo de este trabajo.

Palabras clave: Castellví; linaje; Valencia; siglo XvıI; patrimonio; endeudamiento.

ABSTRACT: The Valencian branch of the Castellví family, which was started in the early five hundreds by the Lord of Puchol, took part in a significant asset accumulation process during the seventeenth century. At the root of it lie the acquisitions carried out by the successive heads of the household. However, the marital strategy of the lineage holders, the 
reduced number of descendants and the reversion to the main bloodline of the bequests from those members of the family who did not get married or died without descendants, proved to be just as important. In contrast, the combination of several factors resulted in a mounting debt. It was particularly pronounced since the 1670 s, when inheritance and debts came together to constitute an unbreakable bond. The purpose of this paper is to analyse the details of this double process and its impact to the Household.

Key words: Castellví; Valencia; Seventeenth century; Assets; Debts.

Es sabido que durante los últimos años asistimos a un creciente interés por los grupos de poder que, a su vez, está favoreciendo el estudio de la nobleza, cuyo indiscutible protagonismo económico, social y político le confiere un lugar preeminente en la evolución del proceso histórico durante la Época Moderna. Trabajos recientes permiten que el panorama historiográfico sobre la nobleza española ofrezca ya significativas aportaciones en las que se presta la atención que merece este grupo, desde perspectivas diferentes y complementarias, entre las que los mecanismos de conformación y transmisión de los patrimonios adquieren un lugar destacado. En esta línea, centrándonos exclusivamente en el caso valenciano, se cuenta con obras generales ${ }^{1}$ y también con análisis de algunos de los más relevantes linajes nobiliarios, caso de los Boïl de Arenós, marqueses de Boïl; los Casalduch-Vallés, barones de la Pobla; los Castellví, marqueses de Villatorcas i condes de Cervelló; los Cervelló, condes de Cervelló; los Mercader, condes de Buñol; los Pardo de la Casta, condes de Alaquás i marqueses de la Casta o los Vilaragut, condes de Olocau y marqueses de Llanera, entre otros ${ }^{2}$. En este marco, la investigación que ahora

1. Sin pretensiones de exhaustividad, en esta línea cabe destacar Gimeno Sanfeliu, M. J.: La oligarquía urbana de Castellón en el siglo XVIII. Castellón, 1990. De la misma autora, Patrimonio, parentesco y poder. Castellón, siglos XVI-XIX. Castellón, 1998. CATALÀ SANZ, J. A.: Rentas y patrimonios de la nobleza valenciana en el siglo XVIII. Madrid, $1995 \mathrm{y}$ del mismo autor «Integridad patrimonial, perpetuidad, memoria. Contradicciones de los mayorazgos valencianos en la época moderna», Studia Historica. Historia Moderna, 33. 2011, pp. 61-95; Brines, J.; Felipo, A.; Gimeno, M. J. y Pérez, C.: Formación y disolución de los grandes patrimonios castellonenses en el Antiguo Régimen. Castellón, 1995.

2. Sirvan a título de ejemplo, Lloret Gómez de Barreda, P.: Ser noble en la València del segle XVII. El llinatge dels Villaragut. Valencia, 2005; Gimeno SAnfeliu, M. J.: Llinatge i poder. Castelló (XVI-XIX). Els barons de la Pobla, la Serra, Borriol, Benicàssim i Montornés. Valencia, 2003; Pérez Torregrosa, G.: «Espacio foral y patronazgo regio. Los Boill de Arenós en el siglo XVII», Saitabi: Revista de la Facultat de Geografia i Història, 60-61, 2010-2011, pp. 255-272; GIL Guerrero, E. M.: «Los Pardo de la Casta. El ascenso de un linaje al servicio regio (siglos XIV-XVII)», Estudis: Revista de historia moderna, 37, 2011, pp. 487-509; FELIPO ORTS, A.: El Conde de Cervelló y el Consejo de Italia: escritos politicos en el exilio austracista (1724-1745). Valencia, 2007. Y de la misma autora, De 
presentamos pretende aproximarse al proceso de acumulación patrimonial de una rama del linaje valenciano de los Castellví durante el siglo xviI, así como a las circunstancias que propiciaron su progresivo endeudamiento.

Los orígenes del linaje que nos ocupa cabe situarlos en Luis de Castellví y Juan -hijo de don Luis de Castellví, señor de Carlet, y de su segunda mujer, doña Juana Juan-, señor de Benimuslem. Casado con doña Leonor Tolsà, su primogénito, don Pedro de Castellví, señor de Benimuslem y Mulata, contrató matrimonio con doña Ángela de Monsoriu -hija del señor de Faura y de doña Violante Ferrer-a quien, en testamento redactado en 1497, instituyó heredera universal con facultad de distribuir sus bienes entre sus hijos según su deseo. Ello confería especial relevancia a las últimas voluntades de doña Angela, quien el 25 de abril de 1508 instituía heredero universal a su hijo primogénito don Luis, que de esta manera sucedía en el vínculo y se convertía en el nuevo señor de Benimuslem y Mulata ${ }^{3}$. Mientras, su hermano don Amberto, señor del lugar de Puchol, iniciaría una nueva rama de la estirpe de los Castellví, que enlaza directamente con los sucesivos personajes objeto de nuestro estudio: don Francisco de Castellví y Castellví, señor de Puchol; don Juan de Castellví y Vich, lugarteniente de portantveus de general governador de Valencia, gobernador de la Orden de Calatrava en los Reinos de Aragón y Valencia y miembro del Consejo de Guerra; don Basilio de Castellví y Pons, gobernador de la Orden de Calatrava, portantveus de general governador de la Ciudad y Reino de Valencia y virrey interino de Valencia en cuatro ocasiones; y, finalmente, don José de Castellví y Alagón, también portantveus de general governador de la Ciudad y Reino de Valencia, virrey de Mallorca durante dos trienios, consejero de capa y espada del Consejo de Aragón y marqués de Villatorcas.

\section{El SEÑORÍO DE PUCHOL Y LAS NUEVAS INCORPORACIONES PATRIMONIALES}

Las primeras noticias de que disponemos sobre don Amberto nos sitúan ante sus capitulaciones matrimoniales con doña Ana de Castellví -hija de don Gilaberto de Castellví y de doña Juana Catalá de Valeriola- firmadas el 20 de enero de 1517 ante el notario Juan Nadal ${ }^{4}$. Fruto de este matrimonio serían don Vicente, don Francisco y don José. Todavía joven, el 23 de febrero de 1529, don Amberto dictó las que acabarían siendo sus últimas voluntades. En ellas, tras revocar cualquier disposición anterior, designar albaceas testamentarios, encomendar su alma a Dios, elegir lugar de sepultura y encargar algunas mandas pías, disponía

nobles, armas y letras. El linaje de los Cervelló en la Valencia del siglo XVII (en prensa) y «Anotaciones sobre la conformación del patrimonio de don José de Castellví, marqués de Villatorcas (1653-1722)», Saitabi: Revista de la Facultat de Geografia i Història, 59, 2009, pp. 171-190.

3. AHN [en adelante AHN], Sección Nobleza. Fondo Fernán Núñez, C. 208, D. 11.

4. AHN, Sección Nobleza. Fondo Fernán Núñez, C. 208, D. 11. 
diversos legados entre sus criados para ocuparse finalmente de su familia más cercana. Así, a su hijo don Francisco le transmitía 25.000 sueldos, bajo vínculo y condición de que si fallecía sin descendientes sucediera en esta suma su hijo don José y, en su defecto, don Vicente. Respecto a don José, manifestaba su voluntad de que abrazara la vida religiosa, obligando al sucesor en el vínculo a costear sus alimentos, estudios y libros hasta que cumpliera 20 años, momento a partir del cual le pasaría una renta anual de 50 libras. Concedía el usufructo de todos los bienes y la tutela de sus hijos a su mujer, doña Ana, que sería sustituida por su hermano Gonzalvo en caso de contraer segundas nupcias o no vivir «castamente». Fallecida esta, instituía heredero universal a don Vicente, en aquellos momentos su primogénito, bajo vínculo y condición de que si moría sin descendientes le sucediera su segundo hijo, don Francisco. Contemplaba también la contingencia de que todos sus hijos murieran sin descendencia, en cuyo caso la sucesión pasaría a Gonzalvo y sus sucesores; y si también este falleciera sin hijos, a su hermano Luis. Dos años después, en febrero de 1531, expiraba don Amberto. En principio don Vicente sucedió a su padre, actuando como tutor su tío don Gonzalvo. No obstante, sabemos que finalmente -seguramente por muerte de don Vicente-sería don Francisco quien se situara al frente de la Casa.

Por su parte, don Francisco de Castellví contrató matrimonio con doña Ana Vich $^{5}$-hija de don Antonio Vich y de doña María de Castellví, hija, a su vez, de don Gaspar de Castellví, sexto barón de Carlet- $-^{6}$ cuyo grado de parentesco exigió una dispensa papal expedida en mayo de $1546^{7}$. El nuevo matrimonio desarrollaría un notorio proceso de ampliación del patrimonio familiar mediante la adquisición de diversas propiedades en el lugar de Museros. En abril de 1553 compraron a don Ángel Pardo de la Casta y doña Violante Vilaragut una casa, 50 cahizadas y 4 hanegadas de tierra situadas en el término de Museros por precio de 16.000 libras, de las que en el acto de venta hicieron efectivas $7.000^{8}$. Durante los años siguientes don Francisco amplió este núcleo inicial con otros inmuebles. Así, en 1566 compró 20 hanegadas de tierra en la partida de Las huitenas por precio de 14 libras; en 1567 una casa y 10 hanegadas de tierra de morera en la partida de San Onofre y 3 cahizadas de tierra en la partida del Molino; y en 1572 siete cahizadas en la partida de Las huitenas por el precio de 321 libras. De esta manera, don

5. Ibidem.

6. Real Academia de la Historia [en adelante RAH], Genealogías, fols. 40-41.

7. AHN, Sección Nobleza, Fondo Fernán Núñez, C. 174, D. 54.

8. Del pago de la suma restante no se conservaba constancia alguna a principios del siglo XVIII, circunstancia que -ante la pretensión de justificar su propiedad- el marqués de Villatorcas argumentó que «aunque no consta de la paga de la restante cantidad está prescrita la acción y por este camino queda asegurada el dominio de dicha heredad», en Idem, C. 1799, D. 3, fols. 4-7. 
Francisco había conseguido acumular un significativo conjunto patrimonial en Museros, que habría de transmitir a sus descendientes9.

El 11 de septiembre de 1598, aquejado de una grave enfermedad, dispuso su testamento ante el notario Francisco Escamilla. En él, tras encomendar su alma a Jesucristo y encargar a sus descendientes la satisfacción de sus deudas, derogaba cualquier disposición anterior, elegía lugar de sepultura y ordenaba sus mandas pías. Sucedían a estas clausulas los legados a sus más próximos. Así, dejaba a su hija Esperanza una dobla de oro en concepto de legítima; a su hija doña Marquesa 50 libras de renta anual; a sus hijas religiosas, sor Ángeles y sor Magdalena, 25 libras en concepto de legítima y 22 libras de renta anual; y a su nieto don Carlos de Castellví y de Salvador 20 libras, en concepto de legítima. Junto a ellos situaba a doña Ana Casanova de Castellví, a quien dejaba 12 libras en agradecimiento de las mercedes dispensadas. Tampoco olvidó a las personas de su servicio y en el resto de sus bienes instituía heredero a su hijo don Juan y sus sucesores, estipulando que si fallecía sin ellos la herencia revirtiera en doña Marquesa y sus legítimos descendientes ${ }^{10}$.

Fallecido don Francisco, el 9 de septiembre de 1598 se procedió a la lectura de su testamento y don Juan aceptó la herencia, «ab benefici de inventari». No obstante, tras una sentencia dictada por el portantveus de general governador-cuya causa y contenido desconocemos- el 3 de enero de 1599 compareció ante el notario Miguel Martí Sanchis para que levantara acta de su repudio de la herencia paterna ${ }^{11}$. Ignoramos las circunstancias que impulsaron la renuncia de don Juan, aunque quizás no fueran ajenas a ella las deudas contraídas por su padre, sobre las que todavía a la altura de 1622 declaraba existir acreedores con pretensiones. De hecho, quizás esta fuera la razón de que, en adelante, desaparezca de la documentación cualquier referencia al lugar de Puchol, del que sabemos que en el censo de población realizado en 1609 era señor don Baltasar Julián ${ }^{12}$. En todo caso, ello no impidió que, como veremos más adelante, acabara recibiendo una parte sustancial de los bienes de su padre.

9. Entre los estudios que se ocupan específicamente de la conformación y transmisión de los patrimonios nobiliarios destacamos, a título de ejemplo, BERNABÉ GIL, D.: «El patrimonio de los marqueses de Rafal (1639-1736). Revista de Historia Moderna, 24, 2006, pp. 253-304. Y del mismo autor «La formación de un patrimonio nobiliario en el Seiscientos valenciano: el primer marqués de Rafal», Revista de Historia Moderna, 5, 1985, pp. 11-66; Brines Blasco, J. y Pérez Aparicio, C.: «La vinculació al País Valencià: origen, transmissió i dissolució dels vincles d’En Guillem Ramon Anglesola» en Homenatge al Doctor Sebastià Garcia Martínez. Valencia, 1988, vol II, pp. 229-252.

10. AHN, Sección Nobleza. Fondo Fernán Núñez, C. 152, D. 3.

11. Ibidem.

12. ReglÁ, J.: Estudios sobre los moriscos. Barcelona, 1974, p. 164. 
2. Don JUAN DE CASTELlví Y VICH. LA SUCESión EN EL VÍNCULO Y LA DECLARACión DE BIENES DE 1622

Así pues, todavía joven, don Juan debía asumir la muerte de su padre, de quien heredó el vínculo instituido en su testamento ${ }^{13}$. Como resulta habitual en este tipo de documentos, este no aporta la relación de los bienes que lo conformaban. No obstante, la justificación de los «Títulos de pertenencia de los bienes de don Josef de Castellví, marqués de Villatorcas», es decir, del biznieto de don Francisco, nos informa con todo detalle de su composición. Se incluían en él todos los adquiridos por compra por don Francisco y situados en el término de Museros: 22 cahizadas de tierra campa y viña y una casa y huerto con 28 cahizadas y 4 hanegadas de tierra; 3 cahizadas de tierra en la partida del Molino; 7 cahizadas de tierra en la partida de Las huitenas; 20 hanegadas de tierra de huerta en la partida anterior; $y$ una casa y 10 hanegadas de tierra de morera. A los bienes incluidos en el vínculo, don Juan pudo sumar a su patrimonio una casa y huerto y otras tierras, también situadas en el término de Museros, de que en 1590 le hizo donación su tía Esperanza de Castellví ${ }^{14}$.

Por otra parte, el real decreto que, en su condición de gobernador de Castellón, exigía la declaración de los bienes que poseía en 1622 nos permite conocer al menos una parte del legado que transmitiría a sus descendientes. Pero también aquellos de los que podía disfrutar con motivo de su matrimonio con doña Luisa Pons. En concreto, declaraba poseer una casa y heredad en el lugar de Museros legados por su padre, que le proporcionaban una renta de alrededor de 500 ducados; la casa en la que vivía en la ciudad de Valencia, heredada también de su padre, que valoraba entre 3.500 y 4.000 ducados; una capilla en el convento de Nuestra Señora del Socorro, donde estaban enterrados sus padres, si bien añadía que «aunque la posee no la tiene por propia»; censos procedentes de la dote de su mujer de propiedad de 9.000 ducados que le producían una renta anual de 500 ducados; y una capilla en el convento de Predicadores que su mujer heredó de sus padres. Aseguraba no tener acciones ni derechos contra nadie pero sí algunos acreedores con demandas contra él por la hacienda que había pertenecido a su padre. Sí pretendía su mujer, doña Luisa Pons, cobrar algunos censos que su madre empeñó y enajenó de la herencia de su padre, el regente Martín Pons.

Declaraba, por otra parte, que en su condición de gobernador de Castellón de la Plana «por el poco salario que tenía en el dicho cargo, le anexó Su Magestad el castillo de Peníscola y todo junto no valía de salario más que 481 ducados».

13. AHN, Sección Nobleza, Fondo Fernán Núñez, C. 152, D. 53. Sobre la actividad política y militar de don Juan, Felipo OrTs, A.: «De los ejércitos reales al Consejo de Guerra. Don Juan de Castellví y Vich (1553-1631)». Estudis. Revista de Historia Moderna, 37, 2011, pp. 273-286.

14. AHN, Sección Nobleza, Fondo Fernán Núñez, C. 1799, D. 3. 
Se añadían a estas las mercedes otorgadas por Felipe III en las Cortes de 1604, que suponían 200 libras de renta sobre la Bailía de Valencia, sumadas a otras 200 libras que tenía consignadas sobre dicha Bailía por merced de Felipe II; y 300 ducados de ayuda de costa para un hijo consignados sobre la misma institución. Por otra parte, como bienes propios declaraba joyas de oro que ascendían a aproximadamente 800 ducados; plata blanca para su servicio valorada en torno a 106 marcos y plata dorada estimada en 40 marcos; 12 tapices y dos antepuertas, un número similar de tafetanes, dos aposentos, cuatro alfombras, doce almohadas de terciopelo carmesí, cuatro camas para «uso personal», dos camas de tafetán y seis camas para «la gente de su casa», conjunto cuyo valor situaba en torno a mil ducados. Conformaban el resto de sus bienes el mobiliario, cuadros «y otros menajes»; un coche con dos mulas y una de respeto y rocines «para la labor»; y cuatro piezas de terciopelo y damasco destinadas a la confección de colgaduras para dos aposentos, cuyo valor situaba en torno a 700 ducados $^{15}$. Junto a ello, representaba que las cargas que respondía anualmente ascendían a 108 libras.

\subsection{La transmisión de bienes. Un supuesto testamento y el codicilo final}

Según su propia confesión, don Juan había otorgado testamento ante el notario Dionisio Alfonso el 27 de mayo de 1623. Pese a ello, en diversos documentos posteriores su hijo don Basilio argumentaba el fallecimiento de su padre «ab intestato». Y también la sentencia dictada por la Real Audiencia el 6 de septiembre de 1631, por la que se le declaraba sucesor en 6.000 libras, admitía que «per les depossicions dels desusdits testimonis en lo present fet e causa produhits e donats, consta e appar lo dit don Johan de Castellví ser mort e pasat de la present vida en l'altra sens haver fet testament ni en altra manera haver dispost de sos béns» ${ }^{16}$. La contradicción se mantiene a finales del siglo Xvir en el documento justificativo del título de pertenencia de la casa y tierras de Museros por el marqués de Villatorcas, nieto de don Juan, cuando unas líneas después de referir que su abuelo murió si testar, escribe: «se advierte que don Juan de Castellví hizo testamento en poder de Dionís Alfonso, notario, en 27 de mayo de 1623 y codicilo a 22 de julio 1629, en poder de Felipe Alfonso, notario». Ignoramos los motivos por los que -al parecer-se quiso silenciar o simplemente desapareció el testamento de don Juan, pero nuestra búsqueda ha resultado infructuosa. En cualquier caso, es obvio que sus últimas voluntades quedaron expresadas en el codicilo de 22 de julio de 1629 en el que aseguraba modificar algunas de sus disposiciones anteriores.

15. Idem, C. 1628, D. 9.

16. Idem, C. 164, D. 23. 
En él don Juan, en ese momento lugarteniente de portantveus de general governador de Valencia y gobernador de la Religión de Calatrava en los reinos de Aragón y Valencia, comenzaba introduciendo algunas variaciones respecto a los albaceas testamentarios, encargaba sus obras pías y mantenía la elección de sepultura. Por otra parte, aunque en su testamento había dispuesto el pago de la dote y creix, ahora -probablemente por falta de liquidez-especificaba que «vull, orden y man que dita dona Luyssa puixa fer pagament prenent de mos béns allò que li pareixerà, així mobles o sitis, fins en tanta cantitat quanta abaste a ser pagada aquella de son dot y creix y augment, volent que en manera alguna no puguen obligar-la a que prenga los censals mateixos que constituhí e apportà en dot, com sia ma voluntat que aquella prenga de mos béns lo que li pareixerà millor y més ben parat ${ }^{17}$. Además, suprimía la obligación impuesta en el documento anterior a su mujer, en su condición de heredera, de conservar el apellido Castellví. Y disponía que los censales de la ciudad de Valencia de propiedad de 2.100 libras, 800 libras y 101 libras, permanecieran inalienables «per tuhició y seguritat de lo que yo vindré a ser alcançat en los contes de la religió de Calatrava. E vull e man que, en tot cas de quitament, les proprietats de aquells se hajen de girar y giren en la Taula de València en nom del governador de la religió de Calatrava que se llavors serà...». Don Juan falleció en 1631 pero no sería hasta el 4 de agosto de 1640, a petición de doña Luisa, cuando se hizo público el testamento ${ }^{18}$.

\section{Don BASILIO DE CASTELLVÍ y PONS y LA AMPLIACIÓN DE LAS PROPIEDADES}

Las primeras noticias sobre la vida pública de don Basilio nos sitúan ante la pretensión de obtener el hábito de Calatrava, cuando apenas tenía 16 años ${ }^{19}$. Pero su posición en el seno de la orden no quedaría limitada a la concesión del hábito. A la muerte de su padre -en ese momento gobernador de la misma en los reinos de Aragón y Valencia- Felipe IV le designó para sucederle en el oficio mediante título expedido el 16 de mayo de 1631. El nombramiento reportaba a don Basilio un evidente prestigio pero también unos ingresos nada desdeñables de 225.000 maravedís anuales, que debía percibir a cargo de las rentas de la Mensa Maestral de la Orden de Calatrava ${ }^{20}$.

En la esfera privada, le veremos desarrollar una estrategia matrimonial que participa de la consanguinidad como fortalecimiento de los vínculos de alianza en el seno del linaje y de la promoción social mediante el entronque con destacadas

17. Idem, C. 153, D. 49.

18. Ibidem.

19. AHN, Órdenes Militares, leg. 520.

20. AHN, Sección Nobleza, Fondo Fernán Núñez, C. 2333, D. 5, n. ${ }^{\circ} 19$. 
casas nobiliarias, según se deduce de sus sucesivos matrimonios con las hijas del regente del Consejo de Aragón don Francisco de Castellví, de los condes de Carlet y de los marqueses de Villasor. Con todo, si por algo adquirieron notoriedad estos enlaces es por el protagonismo alcanzado por la cuestión hereditaria, derivada del fallecimiento de las dos primeras esposas sin descendencia y, muy particularmente, por la problemática suscitada por la restitución de las dotes de las dos últimas ${ }^{21}$.

En sus primeras nupcias, don Basilio contrató matrimonio con doña Francisca Margarita de Castellví -hija del regente don Francisco de Castellví y de doña Eugenia Montoliu- cuya consanguinidad en cuarto grado exigió la obtención de una Bula papal de dispensa, que fue expedida en Roma en $1624^{22}$. De esta manera, el nuevo matrimonio suponía el fortalecimiento de los vínculos de alianza dentro del propio linaje $\mathrm{e}^{23}$ pero quizás fue también la causa de que, tras veinte años de matrimonio, doña Francisca Margarita falleciera el 23 de junio de 1645 sin dejar descendientes de esta unión. Es por ello que en el testamento redactado el día anterior designaba heredero a su marido. Con tal motivo, don Basilio reclamó la herencia que estimaba que le pertenecía y que incluía un riquísimo conjunto de bienes cuya suma total se situaba en la sustanciosa cantidad de 84.264 reales, que finalmente no pudo conseguir.

Cuando apenas había transcurrido algo más de un año, el 22 de noviembre de 1646 don Basilio contrató matrimonio con doña Ana Margarita de Castellví, hija de don Felipe de Castellví, caballero de la orden de Montesa, y de doña Jerónima Blasco, condes de Carlet, quienes, en los correspondientes capítulos matrimoniales, constituían a don Basilio una dote conformada por censales y bienes cuyo valor se elevaba a 20.058 libras. De ellas, se comprometían a hacer efectivos censales de propiedad de 8.358 libras que producían una renta de 696 libras anuales; otras 6.000 libras procederían de dos casas sitas en el lugar de Alberic y diferentes partidas de tierra situadas en los términos de Alberic y Alcosser; y las restantes 6.000 en dinero a entregar en diferentes plazos especificados en las capitulaciones ${ }^{24}$. Por su parte, don Basilio se comprometía a conceder a su futura mujer el

21. Esta cuestión fue tratada en Felipo OrTs, A.: «Los desposorios del gobernador don Basilio de Castellví (1604-1672). Estrategia matrimonial y problemática dotal», Saitabi: revista de la Facultat de Geografia i Història, 60-61, 2011, pp. 237-254.

22. Una copia de la Bula se custodia en el AHN, Sección Nobleza, Fondo Fernán Núñez, C. 174, D. 26.

23. La extensión de este fenómeno en la época moderna en España cuenta con numerosos estudios, entre los que destacamos Chacón Jiménez, F. y Hernández Franco, J. (eds.): Poder, familia y consanguinidad en la España del Antiguo Régimen. Barcelona, 1992; CASEY, J. y HernÁNDEZ FRANCO, J. (eds.): Familia, parentesco y linaje (Historia de la Familia. Una nueva perspectiva sobre la sociedad europea). Murcia, 1997. Para el caso valenciano Catalá SAnZ, J. A.: «El coste económico de la política matrimonial de la nobleza valenciana en la época moderna», Estudis, 19, pp. 165-189.

24. AHN, Sección Nobleza, Fondo Fernán Núñez, C. 174, D. 26. 
creix de 10.029 libras -mitad del valor de la dote- así como a su restitución. En estas condiciones, se celebró una unión matrimonial a la que el fallecimiento de doña Ana Margarita a principios de 1648 puso un pronto final, no sin haber dejado dispuestas sus últimas voluntades en testamento otorgado el 31 de marzo de 1647 en el que nombraba heredero a su marido. Ahora bien, la redacción del primero de los capítulos de acuerdo con los cuales se había pactado el enlace iba a dar pie a una interpretación diversa e interesada y ser utilizada en el pleito que a la muerte de doña Ana Margarita se suscitaría entre su marido y sus padres. Ello no impidió que ya el 28 de abril de 1648 reclamara ante el justicia civil los bienes que alegaba corresponderle de la dote de su mujer. Se trataba de un conjunto de casas y tierras cuyo valor total se situaba en 5.284 libras y 15 sueldos ${ }^{25}$, objeto de un largo litigio con el conde de Carlet.

Desconocemos la sentencia final, pero lo cierto es que ya por entonces don Basilio había iniciado las diligencias que debían conducir a su tercer y último matrimonio con doña Laura de Alagón. El 11 de marzo de 1649 don Blasco de Alagón y Cardona, marqués de Villasor y conde de Montesanto, señor de la baronía de Frangeta, Pantibarigado, Grave y Cosaine en el reino de Cerdeña, señor de Ampurias, Samboy y Cobtas de Balaguer, en el Principado de Cataluña, y Alcalalí y Mosquera, en el Reino de Valencia, y doña Teresa Bazán y Pimentel, otorgaron poder a don Fernando Álvarez de Toledo, conde de Oropesa y virrey de Valencia, para redactar capítulos matrimoniales entre su hermana doña Laura de Alagón y Cardona y don Basilio de Castellví, acordar la constitución de dote a otorgar en contemplación de dicho matrimonio y asentar las cláusulas y cautelas oportunas, en una acta que rubricaron como testimonios don Antonio de Cardona y don Pedro de Castellví y que el notario Pedro Climent protocolizón ${ }^{26}$. Tras complicadas gestiones, derivadas del destino monacal previsto para doña Laura, el 19 de diciembre de 1649 don Basilio de Castellví firmó la carta de pago que justificaba haber recibido 18.000 libras en concepto de dote en el Palacio Real de Valencia. En la misma fecha, se procedió a la firma de los capítulos conducentes a la celebración del matrimonio entre don Basilio y doña Laura. En ellos, los marqueses de Villasor, don Vicente de Alagón y doña Laura, se comprometían conjuntamente a otorgar a don Basilio, en concepto de dote de doña Laura, bienes por valor de 18.000 libras. De ellas, 10.000 «en virtud y per execució de un real decret que sa obtés per a poder constituhir aquelles en dot de la dita señora doña Laura de qualsevol béns sitis del vincle que poseheix del dit señor marqués com ha successor en los béns de dona Anna María Roig de Alagón, sa mare...» ${ }^{27}$. Se

25. Ibidem.

26. Idem, C. 174, D. 25 [A], fols. 2-5

27. Idem, C. 174, D. 11, fol. 24. 
DEL LINAJE DE LOS CASTELLVÍ DURANTE EL SIGLO XVII

trata de una alquería y 12,5 cahizadas de tierra situadas en la huerta de Campanar, valoradas conjuntamente en 7.000 libras; una casa en la Plaza del Mercado de Valencia, estimada en 2.000 libras; y 1.000 libras en un censal de dicha cantidad, que respondía la villa de Sinarcas.

Ahora bien, dado que el decreto real solo autorizaba disponer de bienes vinculados por valor de 10.000 libras, para cubrir las 8.000 restantes se consignaron a don Basilio 300 libras de la renta de las carnicerías del Tosal y 100 libras del alquiler de una alquería en la partida de la cruz de Moncada, usualmente denominada «alquería fonda», cuyo cobro se le concedía hasta que se le adjudicaran en propiedad las 8.000 libras en bienes sitios, libres de vínculo y fideicomiso o cualquier otro cargo ${ }^{28}$. Por su parte, don Basilio se comprometía a conceder el creix, así como a restituir dicha dote en su caso $^{29}$. Pero si en diciembre de 1649 aceptaba las capitulaciones matrimoniales en las condiciones referidas, no tardó en solicitar al monarca la merced de retener durante su vida la dote de su mujer, aunque esta falleciera sin hijos. Felipe IV expidió el correspondiente privilegio con fecha de 6 de abril de 1650, sin embargo don Basilio no podría hacer uso de esta merced. En 1672 fallecía, dejando viuda a doña Laura, quien le sobreviviría hasta 1694.

\subsection{El proceso de acumulación patrimonial. Herencias y compras}

La problemática suscitada en relación con las dotes de sus respectivas mujeres resulta cuanto menos dudosa respecto a las intenciones económicas de don Basilio. Más incuestionable es el hecho de que, por otras vías, protagonizó un significativo proceso de acumulación patrimonial. A él no fue ajena la política matrimonial de los titulares del linaje; el reducido número de hijos tanto de los Pons como de los Castellví; así como la reversión a la línea principal de legados de los miembros de la familia que no contrajeron matrimonio o que fallecieron sin descendencia. En efecto, los años siguientes a su nombramiento como portantveus de general governador en 1644 estuvieron marcados por sucesivas herencias y sucesiones en vínculos $^{30}$, en un proceso en el que se advierte cierta obsesión por parte de don Basilio de su registro mediante declaración del justicia civil o dictamen de la Real Audiencia.

28. Idem, C. 174, D. 11, fol. 26.

29. Idem, fols. 28-29.

30. Sobre la problemática de las sucesiones resulta muy clarificador MARZAL RodríguEz, P.: $E l$ derecho de sucesiones en la Valencia foral y su tránsito a la Nueva Planta. Valencia, 1998. 


\subsection{La sucesión en la casa y tierras de Museros}

Como hemos señalado, don Francisco de Castellví había conseguido acumular un notorio conjunto patrimonial en Museros del que, en contemplación de matrimonio, hizo donación ficticia a su hijo don Juan de Castellví, quien, en documento firmado el 28 de febrero de 1578, «hizo reconoscimiento a favor de dicho don Francisco, su padre, en que declara que la transportación de dichas casas y tierra fue ficta y simulada y para fin de excluir los acreedores de su padre» ${ }^{31}$. Veinte años después, en testamento redactado 1598 -como ya hemos referido-, don Francisco instituyó heredero universal a su hijo don Juan, quien de esta manera pasaba a gozar de manera efectiva de estas propiedades. A ellas todavía sumó en el lugar de Museros una casa con huerto cerrado y otras tierras donadas por sus hermanas, pues en 1596 doña Esperanza de Castellví, señora de Antella, hizo donación de sus bienes a su hermana doña Marquesa de Castellví ${ }^{32}$, quien, a su vez, en documento protocolizado el 25 de febrero de 1605, renunció a favor de su hermano, don Juan de Castellvi3 ${ }^{33}$. Por su parte, don Juan, en testamento de 27 de mayo de 1623 y en los codicilos posteriores de 22 de julio de 1629, instituía heredera universal a su mujer, doña Luisa Pons. Finalmente, doña Luisa, en sus últimas voluntades, dispuestas en enero de 1649 ante Luis Pareja, designaba heredero universal a su hijo don Basilio de Castellvín ${ }^{34}$

\subsection{La sucesión en el vínculo instituido por Leonor Martí de Pons, viuda de Felipe Pons, vicecanciller de la Corona de Aragón}

El origen del vínculo instituido por doña Leonor Martí de Pons cabe situarlo en el testamento otorgado el 19 de junio de 1501 por su marido, Felipe Pons -vicecanciller de la Corona de Aragón-, en el que la instituía heredera universal. Años después, en testamento de 6 de agosto de 1513, publicado en septiembre de 1516, doña Leonor instituyó un vínculo y mayorazgo electivo perpetuo a favor de su hijo Martín Pons y de sus descendientes «in infinitum». Así, su hijo Martín sería el primero en heredar un vínculo, en el que, siguiendo un orden de primogenitura y masculinidad, se sucederían Martín Pons y su hijo Gaspar Pons. La muerte de este último sin descendientes interrumpía la línea directa, pasando la sucesión a su hermano don Luis Pons, a cuya muerte -sin descendencia- en 1616 recaería en fray Martín Pons, miembro de la orden de San Francisco de Paula del convento de San Sebastián. A su vez, fray Martín, previa licencia del general de su orden, hizo

31. AHN. Sección Nobleza, Fondo Fernán Núñez, C. 1799, D. 3, fol. 5.

32. Idem, C. 706, D. 5.

33. Idem, n. ${ }^{\circ} 2$.

34. Idem, C. 1799 , D. 3. fol. 7. 
DEL LINAJE DE LOS CASTELLVÍ DURANTE EL SIGLO XVII

elección a favor de don Basilio de Castellví -hijo de su hermana doña Luisa- en auto recibido por el notario Felipe Alfonso el 14 de mayo de 1630.

Además de la representación de ciertas «nulidades» por parte del convento de San Sebastián, la designación propició una demanda sobre el vínculo por parte de doña Damiata Proxita Pons y Casanova que, presentada ante la Real Audiencia, fue desestimada en sentencia de 1616. No serían estas, sin embargo, las únicas trabas interpuestas a la posesión del vínculo por don Basilio. Figuran entre ellas el proceso sostenido entre doña Antonia Bazán y el convento de San Sebastián -por una partey fray Martín Pons -por otra-, además de otro entre las mismas partes. A estos se sumaron el iniciado por el convento de San Sebastián contra doña Damiata Bazán; el proceso entre don Luis Pons y doña Juana del Milá; el interpuesto por doña Ana Francisca de Proxita contra el convento de San Sebastián y fray Martín Pons; otro, continuación del anterior, en el que se impugnaba la descendencia de doña Ana Proxita, que culminó con una concordia por la que se convino su posesión por don Basilio, que un decreto de la Gobernación ratificó mediante sentencia de 9 de agosto de 1662.

Así pues, la sucesión en este vínculo había resultado azarosa y complicada y muchos de estos procesos concluyeron sin sentencia. Pero, finalmente, don Basilio de Castellví consiguió su propósito y vio reconocidos sus derechos a la sucesión de los bienes que lo conformaban ${ }^{35}$. Se trataba de los siguientes: una alquería, denominada alquería Cremada o de Pons - de la que todavía en la actualidad un antiguo edificio conserva la memoria familiar- y 38 cahizadas de tierra situadas en la partida de San Bernardo de la huerta de Valencia, que Fernando el Católico había concedido al regente Felipe Pons mediante privilegio fechado el 10 de julio de $1486^{36}$. De ella, don Basilio tomó posesión el 12 de diciembre de 1631 con motivo del fallecimiento de su padre, tal como recoge el acta que protocolizó el notario Felipe Alfonso ${ }^{37}$. Se sumaba a ello el peso real de la Ciudad de Xàtiva, del cual

35. Idem, fols. 7-11.

36. Idem, fols. $12-14 \mathrm{v}$.

37. Die XII decembri anno a nativitate Domino 1630...don Basilio de Castellví, cavaller del orde y milicia de Calatrava, habitador en la villa de Madrid cort de Sa Magestat, estant en la alqueria Cremada situada y posada en la horta de la present ciutat de Valencia en la parada de Alboraya pròpia del pare fray Martín Pons, prevere mínimo. Per quant dit fray Martí Pons féu donació de tots los béns y herència de Leonor Martí y Pons al dit don Bacilio post sui obitum ab acte rebut per mi, insfrascrit notari, en catorce dies del propassat mes de maig, e ab dit acte donà facultat al dit don Bacilio pera que pogués prendre posessió de dits béns, inseguint a consiència de aquell havent-me request si rebés acte de la posesio de dita alqueria, y entrant en lo pati de aquella obrí y tancà les portes de dita alqueria y arrancà les herbes.Y, en aprés, accedint a les terres que serán quaranta cafisades poch més o menys, arrancà les herbes de aquella que li paregué, tot en señal de la verdadera, real y actual posesió de dits béns. Y així, en dita conformitat, request per a conservació de sos drets, rebí dit acte en dita alqueria, essent per testimonis a totes les dits coses don Ramón Sans de la Llosa, cavaller del hàbit de Nostra Señora de Montesa, y Francés Buforn, verguer dels jurats de la present ciutat, habitadors de Valencia» en AHN. Sección Nobleza, Fondo Fernán Núñez, C. 164, D. 26, n. ${ }^{\circ} 1$. 
también Fernando II había hecho merced a Felipe Pons en 1486, en compensación por los servicios prestados a la Corona; $\mathrm{y}$, a su muerte, por un nuevo privilegio de 1501, a su hijo Martín Pons. A su vez, este, en testamento redactado en 1573, designó sucesor a su hijo Gaspar Pons, a cuya muerte sin descendientes pasaría, sucesivamente, a su hermano don Luis Pons, fray Martín Pons y Don Basilio de Castellví. Respecto a la tarifa a satisfacer por él, don José de Castellví marqués de Villatorcas, dejó anotado que «en el caxón 17, n. ${ }^{\circ}$ 8, y sub. N. 9 ay un cabreu en que el padre fray Martín Pons, como sucesor en el vínculo de Leonor Martí y de Pons, confesó poseer el peso de la ciudad de Xàtiva tenido baxo directa señoría de Su Magestad a censo cada año de 1 libra 4 dineros, registrado en la segunda mano del libro tercero intitulado cabreu dels emphiteutes que té sa magestad en la present ciutat, fol. 125 en 20 de junio de 1622 custodido en el archivo de la Baylia General de Valencia» ${ }^{38}$.

\subsection{La Casa Grande de la plaza de Predicadores}

La génesis de la que acabaría siendo una pieza clave del patrimonio familiar cabe situarla en la compra de una casa en la plaza de Predicadores por doña Jerónima Castellví, quien en su testamento designaba heredera a su hermana doña Leonor de Castellví y Pons. A su vez, en 1560 doña Leonor designó heredero a su hijo Martín Pons para que dispusiera de la casa a su libre voluntad. Por su parte, don Martín hizo donación de la casa a su nieta doña María Ana Pons -fruto del matrimonio de su hijo homónimo con doña Juana del Milà- a condición de que si esta fallecía sin descendientes pasara al hijo o hija mayor de este matrimonio. En estas condiciones, a partir de 1565 Martín Pons (hijo) inició obras a su propia costa sobre el núcleo inicial, al tiempo que incorporó mediante compra siete casas más. Este ampliado conjunto sería el que recibiría Marco Antonio Pons, quien en su testamento redactado en 1606 instituyó un vínculo perpetuo sobre la llamada Casa Grande y 3.000 libras en propiedad ${ }^{39}$. En él declaraba haber recibido la casa por donación de su madre, doña Juana del Milá y Pons, con motivo de su matrimonio con doña Mariana Figuerola en 1600, si bien aquella se reservaba la facultad de imponer los pactos, vínculos y condiciones que estimara oportunos en favor de los descendientes de este matrimonio. Posteriormente, en testamento redactado en 1605 doña Juana impuso la condición de que si el matrimonio no tuviera descendencia la casa recayera sobre la misma persona que heredara las 3.000 libras. Por su parte, en su testamento Marco Antonio Pons designaba sucesor a su hijo primogénito debiendo iniciarse a partir de entonces un orden

38. Idem, C. 1799, D. 3, fol. 17v.

39. Idem, fols. 22-29. 
de primogenitura y masculinidad pero disponía también que, caso de no tener hijos, la herencia pasara a su sobrino Basilio de Castellví, hijo de su hermana doña Luisa Pons y de don Juan Castellvíi ${ }^{40}$, reservando el usufructo de la casa y de las 3.000 libras para su mujer ${ }^{41}$.

Transcurridos varios años, el 17 de diciembre de 1644 don Basilio de Castellví alegó ante la corte civil de Valencia la ausencia de descendientes y requirió ser reconocido como sucesor ${ }^{42}$, pretensión que, seguida de la preceptiva información de testimonios, concluyó con una sentencia favorable promulgada el 24 de diciembre de $1644^{43}$. Ello suponía que una casa tan emblemática y tan cargada de significado político y cultural -llamada en la documentación «Casa Gran»pasara por derecho de sucesión a él y a sus descendientes.

\subsection{Censos}

Se sumaban a estos bienes un conjunto de censos. Se trata de los siguientes: un censo de propiedad de 650 libras pagado por la recepta real por la morería de Xàtiva ${ }^{44}$; un censo de propiedad de 1.209 libras 19 sueldos y 2 dineros cargado por el señor de Cirat en $1534^{45}$; un censo de propiedad de 3.281 libras, 6 sueldos y 8 dineros cargado por el síndico de la villa de Vallada en 1581; un censo que respondía la villa de Gandia de propiedad de 1.475 libras; un censal de la ciudad de Xàtiva de propiedad de 133 libras y 4 sueldos; un censo de 600 libras que respondía el señor de Manises; un censo de propiedad de 50 libras y, finalmente, diferentes censos de la ciudad de Valencia, y otros que pagaban las villas de Almenara y La Vall d'Uxó, de cuyo valor no tenemos constancia documental ${ }^{46}$.

Resulta obvio que esta suma de herencias permitió a don Basilio de Castellví incorporar un importante conjunto patrimonial, en un proceso en el que se advierte cierta obsesión por su parte por afianzar su registro mediante declaración del justicia civil o dictamen de la Real Audiencia. Así, una sentencia de 17 de diciembre de 1644 reconocía su sucesión en el vínculo instituido por Marco Antonio Pons ${ }^{47}$, que otra posterior de 13 de marzo de 1659 ratificaba $^{48}$. El 13 de abril de 1647 obtenía la declaración de transmisión de todos los bienes de su padre,

40. Idem, leg. $164 / 42$.

41. Idem, leg. $164 / 42$, n. ${ }^{\circ}$ 5, fols. 1-13.

42. Idem, leg. 164/42, fol. 17 .

43. Idem, leg. 164/42, fol. 21.

44. Idem, C. 1799 , D. 3, fols. 18-18v.

45. Idem, fol. 19.

46. Idem, fols. $8 \mathrm{v}-9 \mathrm{v}$.

47. Idem, C. 256. D. 1 , n. ${ }^{\circ} 1$.

48. Idem, C. 208, D. $11, \mathrm{n}^{\circ} 1$. 
don Juan de Castellví, en su condición de único hijo legítimo ${ }^{49}$, así como de 6.000 libras que en sus capitulaciones matrimoniales se había obligado a donar a los hijos del matrimonio ${ }^{50}$. Otra específica sobre la casa y tierras de Museros compradas por su abuelo don Francisco ${ }^{51}$, que todavía revalidaba una sentencia ulterior de 1663. También en 1647 el justicia civil le declaraba sucesor en el vínculo de doña Leonor Martí y Pons, que dos nuevas sentencias de 31 de mayo de 1649 y 15 de febrero de 1659 ratificaron ${ }^{52}$.

\subsection{Las adquisiciones propias. Las fincas urbanas y el lugar de Torcas}

Todavía a estas propiedades don Basilio sumó las que él mismo compró por los mismos años. Así, en 1649 adquirió una casa contigua a la que él habitaba en la plaza de Predicadores por 160 libras; en 1650 otra casa en la calle de Xerea, junto al horno de la Parreta, por 360 libras; en 1653 una casa en la plaza de Predicadores, adquirida al Capítulo de la Seo por 500 libras $^{53}$ y otra casa contigua a la anterior por 200 libras $^{54}$. Queda patente, pues, su estrategia de conseguir entre 1649 y 1653 las casas que lindaban con la propia como medio de consolidar lo que sería una gran propiedad urbana.

Es en este contexto de formación de un sustancioso conjunto patrimonial en el que cabe inscribir la que, sin duda, sería la culminación de un proceso tanto de acumulación de propiedades como de progresión en el ascenso social: la compra del lugar de Torcas ${ }^{55}$. Al respecto, sabemos que en 1664 don Basilio solicitó al monarca un título nobiliario pero que no consiguió ver satisfecha su aspiración ${ }^{56}$. Quizás, la ausencia de respuesta real le impulsara a conseguir un lugar que le permitiera acceder a la condición de señor, pese a su poco saneada economía. En estas condiciones, habiéndose procedido a la subasta del lugar de Torcas -cercano a Segorbe-, hecha la oportuna estimación y las diligencias judiciales necesarias, don

49. Idem, C.164. D. 23, n. ${ }^{\circ} 1$.

50. Idem, C.164. D. 23, n. ${ }^{\circ} 3$.

51. Idem, C. 1799. D. 3, fol. 5v

52. Idem, C.164. D. 26, n. ${ }^{\circ} 2$ y C. 1799. D. 3 , fols. $7 \mathrm{v}-8$.

53. El 22 de julio del mismo año el prior y los mayordomos de la Cofradia de San Jaime le concedían licencia para realizar obras, consistentes en «derrocar de la cuberta de la sala en amunt tan solament» en AHN. Sección Nobleza, Fondo Fernán Núñez, C. 2111. D. 6, n. 2

54. Archivo Municipal de Valencia [en adelante AMV], Manuals de Consells [en adelante MC] 203, fol. 757v.

55. Sobre la compra de lugares e iniciativas colonizadoras como factor del proceso de promoción social durante la segunda mitad del siglo XVII ver Pla Alberola, P. J.: «La jurisdicción alfonsina como aliciente para la recolonización del territorio», Revista de Historia Moderna, 12 , 1993, pp. 79-140. José.

56. La concesión de un título para la Casa se haría esperar hasta 1691 y recaería en su hijo don 
DEL LINAJE DE LOS CASTELLVÍ DURANTE EL SIGLO XVII

Basilio de Castellví ofreció la suma de 4.200 libras. No obstante, las enormes dificultades económicas por las que atravesaba en el momento de la compra le llevaron a pretender vender diferentes partidas de tierra que formaban parte del vínculo de los Pons. Esta circunstancia le exigió solicitar un real decreto que autorizara la venta de las tierras y, en su sustitución, subrogar el lugar de Torcas al vínculo de doña Leonor Martí y Pons. En la correspondiente solicitud, elevada ante la Real Audiencia, don Basilio relacionaba con todo detalle las sucesivas circunstancias que le habían permitido suceder en el vínculo instituido por doña Leonor; refería que entre otros bienes recaían en él la denominada «Alqueria Cremada» y cuarenta hanegadas de tierra contiguas, situadas en la partida de Rascaña de la huerta de Valencia, ubicadas a espaldas del convento de San Miguel de los Reyes; argüía que, acordada la compra del lugar de Torcas, no contaba con bienes más fácilmente disponibles con que adquirirlo, al tiempo que insistía en los beneficios que tanto para él como para sus sucesores derivarían de la sustitución en el vínculo de las tierras por el lugar, que fundamentaba, por encima de cualquier otra consideración, en la consecución del título de señores del lugar, el ejercicio de la jurisdicción, la posesión de vasallos y el disfrute de unos derechos dominicales, frutos, rentas y emolumentos, cuyo valor aseguraba suponer en esos momentos más de 200 libras, que alegaba que una adecuada administración podría aumentar. Todo ello confería a Torcas, según estimación de los expertos, un valor de alrededor de 6.000 libras $^{57}$.

La causa fue cometida al oidor Melchor Sisternes y, realizadas las diligencias pertinentes, la regente firmaba el real decreto favorable a las pretensiones de don Basilio el 25 de enero de 1668 siendo publicado por el escribano de mandamiento Vicente Ferrera al día siguiente ${ }^{58}$. En él se concedía a don Basilio la facultad de vender cuantas cahizadas de tierra, unidas a la citada alquería, estimara necesario para afrontar el pago de las 4.200 libras en que se había tasado el lugar de Torcas. No obstante, se especificaba que la venta la efectuara la Real Audiencia, precediendo pública subasta, y debiendo depositarse las sumas obtenidas en la Taula de Canvis, a suelta de esta institución. Con ellas, el máximo órgano de justicia del Reino debía satisfacer en primer lugar el debitorio y pensiones ${ }^{59}$. Con todo, don Basilio consiguió posteriormente que, prescindiendo de toda formalidad, se le otorgaran plenas facultades para vender -como en efecto hizo- tres cahizadas de tierra situadas en la partida de na Mascona al conde de Sinarcas en pago del debitorio, pensiones y prorrata, que ascendían a 1.467 libras, 7 sueldos y 1 dinero ${ }^{60}$. Además de esta venta, ha quedado constancia documental de otras tres llevadas a cabo por la Real Audiencia en agosto y octubre de 1668. Se trata tres partidas de

57. AHN. Sección Nobleza, Fondo Fernán Núñez, C. 256, D. 1, n. ${ }^{\circ} 9$.

58. Idem, C. 1799, D. 3, fol. 2v.

59. Idem, C. 256, D. 1, n. $^{\circ} 9$.

60. Idem, C. 265 , D. 1 , n. ${ }^{\circ} 1$. 
tierra que sumaban 11,5 cahizadas por las que obtuvo 2.800 libras. Ello comportó que en noviembre de 1668 don Basilio hubiera depositado en la Taula de Canvis 2.732 libras, 12 sueldos y 6 dineros por este concepto. En estas circunstancias, el gobernador solicitó y obtuvo de la Real Audiencia la expedición del oportuno mandato a los oficiales y tablajeros para girar por la Taula dicha suma a nombre de los herederos de Rafael Font de Cardona, vendedores del lugar de Torcas ${ }^{61}$.

Finalmente, concretadas las condiciones, la venta del lugar se protocolizó ante el notario Francisco Iváñez Deza el 14 de noviembre de $1668^{62}$. Solo dos días después, don Basilio solemnizaba la compra y tomaba posesión del señorío por medio de un procurador de acuerdo con el ceremonial acostumbrado. Congregados los habitantes a Consejo General, prestaron juramento de homenaje y fidelidad a don Basilio; le prometieron obediencia y se avinieron al pago de las rentas, frutos, derechos y emolumentos pertenecientes al señor. Acto seguido, en señal de posesión de la jurisdicción civil y criminal, alta y baja, mero y mixto imperio y uso y ejercicio de aquella, despojó de las insignias y bastón a los oficiales, a los que inmediatamente volvió a nombrar y tomó juramento del regimiento de sus oficios; dispuso el arresto de uno de los presentes, arrancó y rompió ramas de los árboles y esparció puñados de tierra; entró en el «palacio eo casa de la señoria», abrió y cerró las puertas y lo mismo hizo con el horno y la tienda. Por encima del carácter ritual, este acto de toma de posesión tiene el interés de solemnizar y exteriorizar la conversión de don Basilio en señor de un lugar, que habría de transmitir a sus herederos ${ }^{63}$.

\subsection{Pese a todo, el progresivo endeudamiento}

Resultado de la incorporación de estas y otras propiedades - de la que queda excluido el lugar de Torcas, que todavía no había adquirido- en la declaración de bienes correspondiente a 1666, efectuada en su condición de «administrador» de la orden de Calatrava, don Basilio representaba la siguiente valoración. El oficio de gobernador de la orden le proporcionaba un salario anual de 600 ducados; su «mayorazgo», bienes libres, gajes y salarios de otros oficios 5.000 ducados anuales; finalmente, la vestimenta, joyas, caballos y demás bienes de su Casa ascendían a 6.000 ducados $^{64}$. Se trataba, sin embargo, de valores estimados y de salarios o gajes no siempre satisfechos pero que, no obstante las elevadas cifras reflejadas,

61. Idem, n. ${ }^{\circ} 10$.

62. Ibidem, C. 265 , D. 1, n. $^{\circ} 1$.

63. Idem, C. 1799, D. 3 , fols. $2 \mathrm{v}-3$.

64. Idem, C. 1628, D. 18. 
resultaron insuficientes para garantizarle la suficiente liquidez que le permitiera evitar su creciente endeudamiento.

De hecho, en un memorial elevado al rey a la altura de 1664 en relación con el salario que percibía por su condición de gobernador de Valencia, aseguraba don Basilio que «se está con el de su primer fundación». Es decir, continuaba estando situado en 1.000 ducados. Es cierto que no había experimentado ascenso alguno desde el siglo xiv, con la evidente disminución del poder adquisitivo de los gobernadores pero también lo es que a esta circunstancia se añadía la derivada de otra cuestión a la que también aludía don Basilio, el incremento de las «obligaciones de lucimiento que los tiempos han introducido». De esta manera, ambos mecanismos, depreciación y ostentación, se habían conjugado para hacer cada vez menos llevaderas las exigencias que comportaba el oficio. Aunque muchas de sus quejas elevadas en relación con el deterioro de su situación económica estuvieran orientadas a suscitar la conmiseración regia en espera de mayores compensaciones, no es menos verídico que fueron muchas las dificultades que hubo de vencer para ver satisfecho el pago de las sumas que se le adeudaban ${ }^{65}$.

La realidad es que Don Basilio había recibido diversas mercedes y oficios por parte de la Corona. En 1634 se le concedió la merced de 220 escudos sobre el obispado de Mallorca ${ }^{66}$. En octubre de 1642 el monarca le hizo merced de un caballerato y nobleza en concepto de ayuda de costa como compensación por los gastos realizados en servicios a la Coron ${ }^{67}$. Respecto a la primera, se quejaba en 1637 de que no se le habían hecho efectivas ${ }^{68}$; y lo mismo volvía a lamentar en 1638,1640 y 1642 en que aseguraba no haberlas percibido con regularidad por obstar determinado impedimento que la documentación no recoge pero que probablemente cabría relacionar con sus constantes ausencias del Reino durante los años precedentes, motivo por el que Felipe IV ordenaba en abril de 1642 al receptor de la Bailía General que

porque todas las vezes que sale de essa ciudad de Valencia o es con orden mío o licencia particular para assitir a cosas de mi Real servicio, me supplica sea servido alçar el impedimento y mandaros le paguéis de aquí adelante sin difficultad alguna, pues sus empeños son notorios y va a servirme en esta jornada con su persona y los montados que le tocan como siempre lo ha echo en todas las compañías que de siete

65. Sobre la difícil situación económica común a los gobernadores, resulta muy útil el trabajo de Bernabé Gil, D.: «Nobles valencianos al servicio regio. La provisión del oficio de portantveus de gobernador Ultra Sexonam en la Edad Moderna», Revista de Historia Moderna, 26, 2008, pp. 24-27.

66. Una copia de la bula en AHN. Sección Nobleza, Fondo Fernán Núñez, CP. 486, D. 9.

67. Archivo Corona de Aragón [en adelante ACA], Consejo de Aragón [en adelante CA] leg. 642, doc. 65/2.

68. ACA, CA., leg. 686, doc. 105/2. 
años a esta parte se han offrecido. Encargo y mando os le paguéis lo que huviere corrido de la dicha renta del tiempo que haya estado ausente con licencia y el que estuviere con ella para lo de adelante y el que fuere ocupado sirviéndome...» ${ }^{69}$.

Pese a todo, la queja se repetiría en $1643^{70}$. Tras las Cortes de 1645 , en consulta de la Junta de materias de 20 de noviembre, Felipe IV otorgó a don Basilio la merced de que se le continuaran pagando las 420 libras de renta sobre la recepta de la Bailía General en concepto de salario. Y así lo comunicaba el monarca a su receptor, don Luis Escrivá, en misiva de 30 de diciembre de $1645^{71}$ y, de nuevo, de 12 de agosto de $1646^{72}$.

Durante los años siguientes percibió puntualmente esta renta hasta 1652 . No obstante, a principios de 1657 se quejaba al monarca de que, a pesar de las cartas reales dirigidas al receptor de la Bailía General para que se hicieran efectivas las sumas adeudadas, en atención a «sus servicios, a la descomodidad con que se halla por su corto patrimonio y moderado sueldo y la obligación que tiene de trattarse con el lucimiento que pide su pueblo» ${ }^{73}$, el receptor había evitado reiteradamente hacer efectivo el pago «respondiendo siempre que no tiene dinero» ${ }^{74}$. Añadía a ello que pese a tener constancia de haber efectuado el receptor pagos a «algunos que no están en su grado y alguna renta atrasada de más de 600 libras», personalmente no había percibido esta renta desde hacía seis años, motivo por el que suplicaba a Felipe IV «sea servido de mandar con su real carta al dicho receptor le pague con efecto, sin réplicas ni escusas, assí todo lo que se le deve hasta oy como lo que en adelante se le deviere, guardándole el grado que le pertenece en virtud de la orden de Vuestra Majestad» ${ }^{75}$. De nada serviría la respuesta real ordenando al receptor que pagara al gobernador «en su grado y lugar» y que explicara las razones por las que no había efectuado los pagos correspondientes; así como a don Basilio de que «diga con individualidad a quien ha pagado el receptor en grado posterior, como en general lo representa» ${ }^{76}$. En misiva de 30 de diciembre de 1659 de nuevo insistía el rey al receptor ${ }^{77}$, y las súplicas de don Basilio -seguidas de la favorable

69. ACA, leg. 906, doc. 126/3. Tenemos constancia de que entre 1631 y 1643 don Basilio tuvo una destacada actuación en algunos de los escenarios bélicos de los ejércitos de Felipe IV relacionados con la revuelta catalana. FELIPO ORTS, A.: «Don Basilio de Castellví y Ponce, gobernador y virrey de Valencia (1604-1673). Apuntes biográficos», en Benítez, R. y Franch, R. (eds.): Estudios de Historia Moderna, en homenaje a la profesora Emilia Salvador Esteban. Vol. I. Valencia, 2008, pp. 171-188.

70. ACA. CA., leg. 886, doc. $105 / 4$.

71. Idem, leg. 922 , doc. $11 / 1$.

72. Idem. CA., leg. 906, doc. 5 y leg. 895 , doc. 66/1.

73. AHN. Consejos, libro 2477, fol. 56.

74. ACA. CA., leg. 906, doc. 126/4.

75. Idem, leg. 906.

76. Ibidem.

77. AHN. Consejos, libro 2478, fol. 43. 
respuesta real- se repetirían en marzo y abril de 1662, en que aducía, además de «los grandes empeños y falta de hazienda con que se halla», el hecho de que se le adeudaban más de catorce años ${ }^{78}$; y en noviembre de 1665 , en que denunciaba un impago que se elevaba ya a más de 16 años $^{79}$, tanto más grave cuanto que su endeudamiento se hacía cada vez mayor, según argumentaba, «por ocasión de las visitas que haze todos los años a las villas reales» ${ }^{80}$.

Y la situación adquirió especial gravedad para don Basilio porque ni siquiera percibió con regularidad las sumas que le correspondían en concepto de salario. Así había ocurrido ya con las que debía cobrar por el desempeño del oficio de lugarteniente de gobernador. Aunque lo había jurado el 6 de febrero de 1624, en agosto de 1628, según constaba en el bureo de Su Majestad, todavía se le adeudaban 34.520 maravedís por lo que montaban los $\left\langle\right.$ gages» ${ }^{81}$. Esta circunstancia se repetiría de nuevo desde 1655 con las cantidades que debía percibir en su condición de alcaide del castillo de Orihuela. Es por ello que en enero de 1658 elevaba al Consejo de Aragón la solicitud de que se le hicieran efectivas las tres tercias correspondientes al año 1655, que ascendían a 250 libras y que el hecho de que Cristóbal Martínez hubiera sucedido en el cargo de receptor a don Antonio Rotglà le impedía cobrar por estimar el nuevo titular que «era deuda de su antecessor y que no podía pagar reçagos sin horden de Vuestra Majestad» ${ }^{82}$. Contrariamente a ello, informaba el Consejo al monarca de que esta suma no podía considerarse como un atraso sino «que queda por quenta corriente de la recepta a cargo de pagar el nuevo receptor». No obstante, la imprecisa respuesta del monarca en el sentido de "guárdese en esto lo resuelto generalmente con todos» impide conocer su verdadera intención. En todo caso, sabemos que idéntica fue la resolución real cuando en septiembre don Basilio elevaba de nuevo la misma súplica ${ }^{83}$ y que solo a principios de febrero de 1659 Felipe IV ordenaba al receptor de Orihuela y Alicante su pago, si bien advertía que en ello debía actuar «guardando las órdenes que tenéis mías» ${ }^{84}$.

Pese a sus reiteradas demandas, no sería hasta enero de 1664, siendo regente de la lugartenencia de la capitanía general, cuando don Basilio obtuviera de manera efectiva 500 ducados, en concepto de ayuda de costa. Fue posiblemente ello lo que le animó a elevar una nueva solicitud al monarca para que le adelantara alguna

78. Idem, libro 2478 , fols. $229,244-244 \mathrm{v}$.

79. ACA. CA., leg. 914 , doc. $16 / 2$.

80. AHN. Consejos, libro 2480, fol. 33-33v. Sobre la problemática de las visitas de los gobernadores a las villas reales, ver BERNABÉ GIL, D.: «Ámbitos de relación entre el poder real y los municipios de la Corona de Aragón durante la época foral moderna», Estudis. Revista de Historia Moderna, 32, 2006, pp. 59-67.

81. AHN. Sección Nobleza, Fondo Fernán Núñez, leg. 705/9, n. ${ }^{\circ} 4$.

82. ACA. CA., leg. 906, doc. 126/1.

83. Idem. leg. 906.

84. AHN. Consejos, libro 2477, fol. 180. 
cantidad a cuenta de los salarios que se le adeudaban a fin de poder hacer frente a los enormes gastos que su nuevo cargo comportaba ${ }^{85}$.

\subsection{Los gastos del matrimonio de su primogénito y el empeño de bienes a la Ciudad de Valencia}

Con todo, la negativa situación económica de la Casa parecía haber llegado a su extremo cuando don Basilio se vio obligado a hacer frente a los gastos derivados del matrimonio de su primogénito. Ante esta circunstancia, reconociendo el endeudamiento que padecía, en mayo de 1671 solicitó de la regente el pago de las 400 libras de renta de la recepta de Valencia que por el cargo de gobernador le correspondían y que no había percibido desde hacía muchos años ${ }^{86}$.

No obstante, la respuesta real de que «esto tiene inconveniente» cerraba esta puerta a la esperanza de don Basilio, lo que no le impediría continuar insistiendo mediante otros argumentos. En efecto, el 9 de abril de 1672, con motivo del contrato matrimonial de su hijo don José con doña Guiomar Coloma, hija de los condes de Anna y Elda, don Basilio representó que «a ocasió de dit casament se li offereixen execessius gastos que no es poden escussar, com és en gales, joyes, alaixes y coches y tot lo demés que porta en sí semblant funció, que ademés de lo necessari y precís concurriexen altres coses que la observància y ús les a fetes de la mateixa calitat y no es poden escusar ${ }^{87}$. Circunstancia que en este caso refería el gobernador verse incrementada por la propia condición de los contrayentes. A la pertenencia a familia «tan calificada com és la de Castellvins», añadía respecto a su hijo el hecho de tener concedida la gracia real de la sucesión en el oficio de portantveus de general governador y la preeminencia del título de la Gobernación; de doña Guiomar, la calidad de su Casa. En estas condiciones, considerando ineludible afrontar los elevados gastos que comportaba la celebración, don Basilio no veía otra posibilidad que la de recurrir a la venta de algunas propiedades «perquè sent com són tan grans los gastos y excessives les cantitats que són menester, no poden abastar les rentes, màxime estant com està tan empeñat, tenint la major part de les alaixes empeñades y no trobant-se en diner contat algú, pues encara $a b$ les rentes fa prou de sustentar sa Cassa» ${ }^{88}$. Es más, añadía que para obtener la dispensa y caballerato para poderse casar, don José se había empeñado en más de 1.000 libras que esperaba recuperar a partir de la pensión apostólica de que gozaba

85. ACA. CA., leg. 912, doc. 11 .

86. Idem, CA., leg. 906, doc. 196.

87. AMV. MC. 203, fol. 755 .

88. Idem, fol. $755 \mathrm{v}$. 
y que, habiendo intentado vender algunos bienes libres, no había sido posible por no encontrar quien los adquiriera.

En esta situación, don Basilio estimó más viable buscar quien adquiera el derecho de recobrar 300 libras de renta anual que la Ciudad respondía sobre las carnicerías del Tosal, que formaban parte de la dote aportada por su mujer, doña Laura de Alagón. No obstante, no pudiendo vender tampoco el derecho de dicha consignación, trató de empeñarlo a la Ciudad por 5.000 libras con derecho de restitución. En garantía de esta cantidad concedía a la Ciudad la posesión de una casa grande sita en la ciudad de Valencia en la calle de San Vicente y una casa grande y huerto en el lugar de Museros valorados en 3.000 y 6.000 libras respectivamente ${ }^{89}$. Se sumaban a estas propiedades el conjunto de casas que don Basilio había adquirido entre 1649 y 1653 . Por otra parte, el valor de las propiedades libres que empeñaba a la ciudad se elevaba a 8.728 libras. A ellas se añadían las 8.000 libras que los marqueses de Villasor habían accedido a aportar con esta ocasión, lo que situaba la suma total en cerca de 17.000 libras. A partir de ellas, la Ciudad se iría resarciendo de la deuda mediante los frutos y alquileres de las propiedades ${ }^{90}$. En estas condiciones, la suplicación fue evocada ante la Real Audiencia y atendida por Melchor Sisternes, quien inició el proceso con la preceptiva información de testimonios ${ }^{91}$.

Tras las pertinentes diligencias, la sentencia favorable de la Real Audiencia, permitió que el 18 de mayo de 1672 se firmara acto de «venda feta e fermada per los illustres don Basilio de Castellví y Pons, portantveus de general governador y doña Laura de Alagón Arborea y Cardona, coniuges, a favor de la illustre e insigne ciutat de València del dret de recobrar de la mateixa Ciutat trescentes liures annues que la dita y mateixa Ciutat li respon per consignació dels marquesos de Villasor sobre les carniceries del Tosal per preu de 5.000 lliures» ${ }^{92}$. A él sucedió el acto de toma de posesión por parte de la Ciudad, y en su representación del subsíndico José Mateu, quien, acompañado de un notario y de varios testigos, se personó en cada una de las propiedades llevando a cabo la representación de toma de posesión protocolaria en estos casos, tanto en Museros como en Valencia ${ }^{93}$. Aunque reconocía don Basilio que 5.000 libras no bastarían para cubrir los gastos que conllevaba el matrimonio de su hijo, hipotecar sus bienes le permitiría afrontar con mayor desahogo la celebración.

89. Idem, fol. 757.

90. Idem, fol. 757-759.

91. Idem, fols. $759 \mathrm{v}-768 \mathrm{v}$.

92. Idem, fols. 775-786.

93. Idem, fols. $791 \mathrm{v}-792$. 


\subsection{La transmisión bereditaria y la reclamación por doña Laura de las sumas} adeudadas a su marido

El 14 de junio de 1672 don Basilio de Castellví disponía sus últimas voluntades ante el notario Francisco Yáñez Deza. En ellas, tras revocar cualquier disposición testamentaria anterior, manifestar su deseo de que se saldaran sus deudas, nombrar albaceas, disponer sus obras pías, elegir lugar de sepultura y encomendar ser enterrado revestido con el hábito e insignias militares de la orden de Calatrava, legaba a esta orden un doblón de oro en concepto de legítima. Dejaba a doña Guiomar Coloma -hija de los condes de Elda y Anna-, con quien se había capitulado el matrimonio de su hijo don José, un reloj de porcelana y una gargantilla de diamantes y delegaba en su mujer la compensación de los servicios de sus criados y la liberación de alguno de sus esclavos. En el resto de los bienes que en ese momento poseía y en los que en el futuro le pudieran pertenecer instituía heredera -con carácter vitalicio- a su mujer, a cuyo fallecimiento pasarían a su hijo don José ${ }^{44}$, excepción hecha de la denominada Alquería Cremada y tierras anexas de las que designaba heredero directamente a su hijo ${ }^{95}$.

Unos meses después, el 23 de agosto de 1672, fallecía don Basilio. En la esfera pública y política sería don José de Castellví, futuro marqués de Villatorcas, quien recogiera el testigo; en la privada, su viuda doña Laura, asumía la herencia pero también la ardua misión de intentar recobrar por todos los medios las sumas que reiteradamente había demandado don Basilio sin que se le hubieran hecho efectivas. En principio, a petición suya, en agosto de 1672 el maestre racional Jerónimo Zanoguera certificaba que don Basilio había obtenido mediante tres mercedes sucesivas que de la recepta de la Bailía General se le hicieran efectivas 210 libras anuales, además de otras dos partidas de 100 libras por dos años, y acreditaba que de estas solo constaba haber recibido la de 210 libras hasta 1655; una de las de 100 hasta 1655; y la otra hasta 1654 y que «havent reconegut los demés contes fins lo de 1670 (que és lo últim que ya presentat), de dita recepta no consta se haja pagat a dit governador, ni a altra persona per aquell, cantitat alguna per dita raó» ${ }^{96}$. Como alegaba doña Laura en la misiva que el 27 de agosto de 1672 elevó a la regente, ello suponía que en esos momentos el montante de la deuda ascendía a más de 8.000 libras, mientras los gastos familiares se habían incrementado, por cuanto los derivados del «cumplimiento del testamento» y los de la obtención de los privilegios de gobernador y de castellano del castillo de Orihuela para don José sumaban más de 7.000 reales de plata. Por todo ello, suplicaba a la regente que se le librara alguna cantidad «la que a Vuestra Magestad fuere servida, por

94. AHN. Sección Nobleza, Fondo Fernán Núñez, leg. 154/4.

95. Ibidem.

96. ACA. C.A., leg. 642 , doc. 3. 
DEL LINAJE DE LOS CASTELLVÍ DURANTE EL SIGLO XVII

una vez, por quenta de este crédito, en consideración de los servicios del dicho su marido, de la gran falta de medios con que se halla, en ocasión que a de casar a don Joseph, su hijo, y de que aún para alimentarse no tiene forma» ${ }^{97}$. Aunque en esta ocasión, la regente dispuso que por no contar la Recepta con medios para afrontar la petición se buscara algún expediente mediante el cual obtener 500 ducados, parece que finalmente no se le hicieron efectivos. Lo cierto es que en enero de 1673 doña Laura elevaba otra solicitud, a la que en este momento se respondió que se propusieran arbitrios que permitieran incrementar a 1.000 reales de plata los 500 ducados aceptados en agosto de $1672^{98}$. Pero -como refería doña Laura en abril de 1673- tampoco la concesión tuvo efecto alguno ${ }^{99}$.

La imposibilidad de obtener las sumas adeudadas determinó a la viuda del gobernador a solicitar otras vías de compensación. Así, en junio de 1673 pidió facultad para «beneficiar dichas mil libras en el Reyno de Cerdeña, ora sea en algún cavallerato, o en otro qualquier efeto en el que se hallase» ${ }^{100}$. En febrero de 1674 la súplica insistía en que hiciera efectiva la cantidad, «de lo procedido y que procediere de los embargos y composiciones de franceses de aquel Reyno» ${ }^{101}$. Esta segunda propuesta no se aceptó bajo la consideración de que «estos effectos están aplicados para la guerra». No obstante, sí consiguió cobrar 500 de las libras prometidas mediante la concesión de un caballerato del Reino de Cerdeña a favor de Antiogo Marroco. Para recuperar las 500 restantes propuso que se le concediera permiso para liberar a dos delincuentes. Tan sorprendente proposición, tuvo, sin embargo, por respuesta, fechada en febrero de 1675, «escrívase al virrey de Valencia con relación de lo que contiene este memorial y pide la suplicante. Y que, si por su parte se le propusieron estos delinqüentes, informe de la calidad de los delitos y diga su parecer sobre la remisión para que con noticia dello se pueda tomar resolución» ${ }^{102}$. Por su parte, examinada la propuesta de doña Laura de liberar a José Adriá de la villa de Liria, en el informe que el virrey, conde de Paredes, elevó al monarca en abril de 1675 comunicaba que «parece cave en él la gracia» ${ }^{103}$.

Con todo, no acabaron aquí sus peticiones. En marzo de 1676 volvía a la carga solicitando la merced de un caballerato con voto en Cortes como «alivio de sus ahogos» y como medio de satisfacer sus muchas deudas. No obstante, en la consulta que hizo llegar al monarca, el Consejo de Aragón, tras recordarle las anteriores concesiones y el hecho de que se estaba negociando otorgarle otro

\footnotetext{
97. Idem, doc. $114 / 2$.

98. Idem, doc. 114/1.

99. Idem, doc. $114 / 4$.

100. Idem, doc. $114 / 5$.

101. Idem, doc. $114 / 6$.

102. Idem, doc. $114 / 7$.

103. Idem, doc. 8 .
} 
«caballerato y nobleza» en el Reino de Cerdeña, aconsejaba ofrecerle 500 ducados «con que pareçe se puede escussar la gracia que pide, y particularmente por los incombenientes que tiene el hacerlas con voto en Cortes en Valencia», aduciendo ser esa la razón por la que Felipe IV había prohibido que se concedieran este tipo de mercedes, parecer con el que el monarca se conformó ${ }^{104}$. Quedaba así sin satisfacción la pretensión de doña Laura. Pero no sería esta su última demanda. En enero de 1678 pedía la restitución de las sumas adeudadas a partir de las sacas del Reino de Cerdeña. También ahora el Consejo se apresuró a advertir al rey de la dificultad de hacer servir esta vía por la falta de medios en Cerdeña, sugiriendo que se ofreciera a la suplicante una carta destinada al virrey y a la Junta Patrimonial de Valencia para que se le pagara «en su grado y lugar». Pero, obviamente, tantos años de demandas insatisfechas por esta vía determinaron que doña Laura rehusara el ofrecimiento, tal como quedó anotado en la correspondiente consulta: «no quiso la parte esta carta» ${ }^{105}$. Por consiguiente, una vez más, su petición quedaba sin solución favorable. Y a ellas todavía podemos añadir otra documentada en mayo de 1689 , con idénticos resultados ${ }^{106}$.

Parece que, transcurridos más de quince años desde que falleciera el gobernador, su viuda no había conseguido recuperar más que una ínfima parte de las sumas que se le seguían debiendo. Su propio testamento rezuma el desasosiego de una mujer que advierte que sus días se apagan sin poder satisfacer siquiera sus propios débitos.

\section{El testamento E inventario de bienes de doña laura de alagón y la SUCESIÓN DE DON JOSÉ}

En efecto, el 20 de agosto de 1694 doña Laura de Alagón y Cardona, dama de honor de la reina, afectada por una enfermedad que hacía temer por su vida, otorgó testamento en el palacio real de Madrid. En él, tras encomendar su alma a Dios y disponer su sepultura en la bóveda de Nuestra Señora del Rosario del convento de Santo Tomás de la Orden de Predicadores de Madrid, revestida con el hábito de San Francisco, dejaba su entierro a criterio de sus albaceas, con la petición añadida de que «si los bienes que dexare no alcansaren a los gastos de dicho entierro, pido y suplico al rey nuestro señor (Dios le guarde) sea servido de suplirlos en atención a su gran benignidad y buena ley, con que a Su Magestad le he servido", que apunta a una falta de solvencia, que también traslucen otras cláusulas que muestran su especial preocupación por dejar constancia escrita de

104. Idem, leg. 642 , doc. $114 / 10-11$.

105. Idem, leg. 916 , doc. $97 / 1$.

106. Idem, leg. 642 , doc. 90 . 
sus deudas económicas y personales y su manifiesto deseo de que sus albaceas testamentarios las repararan.

Es el caso de su manifiesta voluntad de que se resarciera la deuda pendiente con Juan de Betalesa y Compañía, mercaderes de seda en la puerta de Guadalajara, y con un mercader de lienzos -cuyo nombre no se especificaba-con los que exponía haber tenido «algunas dependencias de mercaderías»; o de la contraída durante dos años con don Fernando Alterra, médico de familia de Su Magestad, que le asistió en sus enfermedades y en las de sus parientes. Y tampoco olvidó a las personas de su servicio, en particular a su criada doña Gabriela Garcí Sánchez de Oros, que la había acompañado durante 15 años en los viajes realizados en servicio de la reina, para quien solicitaba al monarca que la honrara «con ocupación y empleo que corresponda al estado con quien puede passar a tomar estado». También le pedía que atendiera a todas sus criadas «en consideración a no dexarme Dios con qué poderlas remunerar el trabajo que en mi asistencia han tenido». Declaraba, en sentido contrario, que el monarca le adeudaba «diferentes cantidades de maravedís muy considerables», que solicitaba que se hicieran efectivas en su heredero o herederos. Como albaceas facultados para vender en pública subasta cuantos bienes fuera necesario para cumplir las estipulaciones del testamento nombraba al conde de Puñoenrostro, al marqués de Villatorcas, a fray Mateo Caro de Montenegro, a don Lucas de Ordobas, presbítero y capellán de honor de Su Magestad, y a fray Juan de Perea ${ }^{107}$.

En el resto de sus bienes muebles y raíces, derechos y acciones instituía heredero universal a su hijo, el marqués de Villatorcas. Inventariados estos el 14 de septiembre de 1694, comprendían un amplio conjunto de muebles, entre los que destacan escritorios de madera de ébano decorados con marfil, veladores, bufetes, tocadores, vitrinas -entre las que sobresale una ricamente decorada con una imagen de plata de la Inmaculada Concepción-, camas, baúles... Se incluían también ocho cuadros en los que -junto al retrato del rey-dominaba la temática religiosa, con preeminencia de imágenes de vírgenes bajo diferentes advocaciones -Nuestra Señora del Sagrario, del Traspaso y de la Contemplación- representaciones de Cristo -Nacimiento, Descendimiento, Adoración de los Reyes- y de san Pedro de Alcántara. Constituían un apartado importante y de considerable riqueza las piezas de plata y, muy especialmente, las valiosísimas joyas incrustadas con piedras preciosas -esmeraldas, diamantes y rubíes- entre las que sobresalen un fastuoso pectoral, relicarios, cajas de oro con piedras incrustadas y riquísimos rosarios, aunque también se incluyan gargantillas, pendientes o sortijas. Un estimable ajuar doméstico de «ropa blanca», vestidos y complementos y menaje de cocina completaban el conjunto de bienes que legaba a don José. Poseía, asimismo, doña

107. AHN, Sección Nobleza, fondo Fernán Núñez, C-154, D. 18. 
Laura una pequeña colección de 14 libros cuya mera transcripción nos ilustra sobre las que serían sus preferencias en el ámbito de la lectura y, podríamos aventurar, que de la espiritualidad ${ }^{108}$.

Por otra parte, de acuerdo con el testamento de su marido, sería doña Laura quien usufructuara la mayor parte de los bienes de don Basilio hasta que a su muerte en 1694 pasaran plenamente al marqués de Villatorcas. Desde este momento, don José percibía los bienes transmitidos por sus abuelos paternos y por su padre ${ }^{109}$. Se añadían a ellos el goce del dominio, propiedad y usufructo de los bienes, casas, censales, rentas, derechos y acciones recayentes y que pudieran recaer en las herencias, vínculos y mayorazgos de Marco Antonio Pons ${ }^{110}$; los bienes, derechos y acciones recayentes en el vínculo instituido por doña Leonor Martí, viuda y heredera del vicecanciller don José Pons, conformados por diferentes heredades, censos, el peso de la ciudad de Xàtiva y el lugar de Villatorcas ${ }^{111}$. De esta manera, don José de Castellví y Alagón, marqués de Villatorcas, recibía una herencia que, en definitiva, no era más que la expresión de una constante vital que había acompañado al linaje durante toda la centuria y en la que patrimonio $\mathrm{y}$ endeudamiento se aliaban en permanente complicidad. En los años siguientes

108. Se trata de los siguientes: «Un libro que se intitula Fray Luis de Granada.Más la benerable Madre Rocaberttí de los estados. Más dos tomos de los sagrados huesos de Christo. Más otro tomo, Templo del Espíritu Santo. Más un memorial que se intitula Crisol de la verdad. Más un libro que se intitula Sermones de San Luis Beltrán con paz de preffectos. Más la vida de Santo Domingo de Siles. Más un libro que se intitula ydea de exemplar de prelado. Más la vida del beato Pascual Baylon. Más un libro que se intitula Catecismo con el rossario. Más un libro que se intitula Temor de Dios e himitaciones tenporales. Más un libro que se intitula Vida de la sereníssima ynfanta sor Margarita de la Cruz. Más un libro que se intitula Flos Antonio de Villegas, primera y segunda parte. Más un libro que se intitula Fundaciones de los ospitales de Arjel» en Idem, C. 1628, D. 23.

109. "Otrosí, de todos los bienes, drechos y acciones recayentes en la herencia del condam señor don Joan de Castelví y de la señora doña Luisa Pons y del señor don Bacilio de Castelví, padre del dicho señor marqués, del Consejo que fue de su Magestad y su governador de esta ciudad y reino, que pertenecieron a dicho illustre señor marqués, según los testamentos de dicho señor don Joan de Castellví, recibido por el ya citado Dionisio Alfonso, notario, en veinte y tres de mayo mil seiscientos veinte y tres y de la señora doña Luisa Pons ante Luis Pareja, notario, a onze de diciembre mil seiscientos quarenta y ocho, y el de dicho señor don Basilio de Castellví, recibido por Francisco Ibáñez Desa, notario, en catorze de junio mil seiscientos setenta y dos» en Idem, C. 1273, D. 9.

110. De acuerdo con lo dispuesto en su último testamento, «bajo cuya disposición murió, recibido y publicado por Dionisio Alfonso, notario, en diez de julio del año pasado de mil seiscientos y seis y en diez de julio de mil seiscientos y diez, en que recahen la casa principal de Predicadores de esta ciudad, enfrente la puerta por donde se entra a la Iglesia del Convento de Santo Domingo, y todas las agregadas a dicha casa, diferentes bienes y censales» en Ibidem.

111. «Otrosí, de todos los bienes, derechos y acciones recayentes en el vínculo instituydo por la señora doña Leonor Martí, viuda y heredera del señor vicecanciller don Joseph Pons, en su último testamento, bajo cuya disposición murió, que pasó ante Pedro Murta, notario, a seis de agosto mil quinientos treze, y publicado a siete de setiembre mil quinientos diez y seis, que es electivo, $\mathrm{y}$ usando de la elección concedida al dicho señor marqués, en el qual recaen diferentes heredades, censos, el peso de la ciudad de Xàtiva y el lugar de Villatorcas» en Ibidem. 
sería él quien tuviera que asumir una situación económica familiar no exenta de nuevos, graves y complejos contratiempos.

\section{A MODO DE RECAPITULACIÓN}

De la investigación realizada se desprende que, hijo segundón del señor de Benimuslem y Mulata, don Amberto de Castellví, señor de Puchol, inició una nueva rama del linaje de los Castellví cuya consolidación, además de un pequeño señorío, exigiría la conformación de un sólido patrimonio. Es por ello que su primogénito don Francisco emprendió un proceso de ampliación de la propiedad familiar mediante la adquisición de diversas posesiones en el lugar de Museros sobre las que instituyó un vínculo, al que su sucesor pudo sumar el legado de su hermana. Con todo, sería don Basilio de Castellví y Pons quien protagonizara una acumulación patrimonial más acentuada. En ella confluyó la política matrimonial de los titulares del linaje; el reducido número de hijos tanto de los Pons como de los Castellví y la reversión a la linea principal de legados de los miembros de la familia que no contrajeron matrimonio o que fallecieron sin descendencia. Esta conjunción de factores favoreció que durante la década de 1640 aunara en su persona sucesivas herencias y sucesiones en vínculos que le permitieron suceder en la casa y tierras de Museros, en el vínculo instituido por Leonor Martí de Pons, en la Casa Grande de la plaza de Predicadores y en abundantes censos.Todavía, culminación del proceso serían sus adquisiciones propias, conformadas por un conjunto de casas, que constituyeron una gran propiedad urbana, y por la compra del lugar de Torcas, de destacado significado por cuanto le elevaba a la condición de señor, aunque para ello se viera obligado a intercambiarlo por tierras que formaban parte del vínculo de los Pons.

Pese a la entidad de este patrimonio no pudo evitar que su consecución fuera pareja a un progresivo endeudamiento, fenómeno común a muchos gobernadores. En un minucioso estudio de las condiciones en que debían desarrollar sus funciones, David Bernabé demostró que la escasa remuneración económica, que difícilmente compensaba las incomodidades de comportaba un cargo que exigía constantes viajes, la manutención de dos residencias, los gastos de representación, los dispendios extraordinarios..., llevaría a muchos de los propuestos para el oficio de portantveus de governador Ultra Sexonam a renunciar o simplemente a no aceptar el oficio; e incluso a que muchos de ellos acabaran sus días en una situación económica menos favorable que la que tenían en el momento de jurar el cargo ${ }^{112}$. De esta realidad también participaban los gobernadores de Valencia. Quizás el caso del propio don Basilio de Castellví pueda resultar paradigmático en este sentido. Aunque muchas de sus quejas elevadas en relación con su grave

112. Bernabé GIL, D.: «Nobles valencianos al servicio regio...», pp. 24-27. 
situación económica estuvieran orientadas a suscitar la compasión regia, no es menos cierto que fueron enormes las dificultades que hubo de vencer para ver satisfecho el pago de las sumas que se le adeudaban. Ahora bien, el deterioro económico de la Casa se hizo especialmente patente cuando don Basilio hubo de afrontar los elevados gastos derivados del matrimonio de su primogénito, futuro marqués de Villatorcas, a principios de la década de 1670. Ello le condujo al extremo de empeñar a la Ciudad de Valencia el cobro de 300 libras de renta anual sobre las carnicerías del Tosal por 5.000 libras, cediendo en garantía la posesión de un conjunto de bienes vinculados, constituidos por una una casa grande en la calle de San Vicente, todas las propiedades urbanas que había adquirido entre 1649 y 1653 y una casa grande y huerto en el lugar de Museros. Se sumaban a ellos bienes libres por valor de más de 8.000 libras, junto a otras 8.000 que los marqueses de Villasor accedieron a aportar con esta ocasión. Aunque la medida comportó un alivio momentáneo, lo cierto es que, pese a los denodados esfuerzos de su viuda, transcurridos más de quince años desde que falleciera don Basilio, no había conseguido recuperar más que una ínfima parte de lo que se le seguía adeudando. Es más, su propio testamento evidencia que, a mediados de la década de los noventa, las finanzas familiares no se habían recuperado. En definitiva, estas páginas destapan el doble proceso de acumulación patrimonial y de progresivo endeudamiento protagonizado por esta rama del linaje de los Castellví durante una centuria crucial para la Casa, así como a las circunstancias que lo condicionaron.

\section{Bibliografía}

Bernabé GiL, D.: «El patrimonio de los marqueses de Rafal (1639-1736), Revista de Historia Moderna, $\mathrm{n}^{\circ}$ 24, 2006, pp. 253-304.

Brines, J.; Felipo, A.; Gimeno, M. J. y Pérez, M. C.: Formación y disolución de los grandes patrimonios castellonenses en el Antiguo Régimen. Castellón, 1997.

Casey, J. y Hernández Franco, J. (eds.): Familia, parentesco y linaje (Historia de la Familia. Una nueva perspectiva sobre la sociedad europea). Murcia, 1997.

Catalá Sanz, J. A.: Rentas y patrimonios de la nobleza valenciana en el siglo XVIII. Madrid, 1995.

Catalá SAnZ, J. A.: «El coste económico de la política matrimonial de la nobleza valenciana en la época moderna», Estudis, 19, 1993, pp. 165-189.

Chacón Jiménez, F. y Hernández Franco, J. (eds.): Poder, familia y consanguinidad en la España del Antiguo Régimen. Barcelona, 1992.

Felipo Orts, A.: «De los ejércitos reales al Consejo de Guerra. Don Francisco de Castellví y Vich (1553-1631)», Estudis. Revista de Historia Moderna, nº 37, 2011, pp. 273-286.

Felipo OrTs, A.: «Los desposorios del gobernador don Basilio de Castellví (1604-1672). Estrategia matrimonial y problemática dotal», Saitabi. Vol. 60-61, 2011, pp. 237-254.

REgLÁ, J.: Estudios sobre los moriscos. Barcelona, 1974, p. 164. 